\title{
Transition-Metal Catalyzed Synthesis of Ketoprofen
}

\author{
Carolina Ramminger, Danilo Zim, Vanusa R. Lando, Viviane Fassina and Adriano L. Monteiro*
}

\author{
Instituto de Química, Universidade Federal do Rio Grande do Sul, CP 15003, 91501-970, Porto Alegre - RS, Brazil
}

\begin{abstract}
Reações catalisadas por complexos de metais de transição tais como carbonilação, hidrovinilação e hidrogenação foram empregadas na síntese do ácido $\alpha$-(3-benzoilfenil)propanóico (Cetoprofeno). Acoplamento do tipo Heck entre 3-bromobenzofenona e etileno conduziu à 3-vinilbenzofenona que na sequência, por carbonilação catalisada por paládio, foi tranformada no $\alpha$-(3benzoilfenil)propanoato de isopropila com rendimento de $95 \%$ e regiosseletividade $>99,5 \%$. Hidrólise deste éster conduziu ao Cetoprofeno com $90 \%$ de rendimento. Cetoprofeno foi também obtido em duas etapas a partir da 3-vinilbenzofenona via reação de hidrovinilação catalisada por níquel que conduz seletivamente ao 3-(3'-benzoilfenil)-1-buteno (96\%), seguido por oxidação desta olefina em ácido. A 3-etenilbenzofenona pôde ser sintetizada a partir da 3-bromobenzofenona via uma reação de acoplamento catalisada por paládio. Este alcino foi carabonilado em presença de paládio conduzindo regiosseletivamente $(97 \%)$ ao $\alpha$-(3-benzoilfenil)acrilato de metila. A hidrólise do éster conduz ao ácido $\alpha$-(3-benzoilfenil)acrílico que foi então hidrogenado enantiosseletivamente ao (S)-Cetoprofeno (95\% e.e.) usando um complexo Ru-(S)-BINAP como catalisador.
\end{abstract}

Transition metal-catalyzed reactions including carbonylations, hydrovinylations and hydrogenations have been applied in the synthesis of $\alpha$-(3-benzoylphenyl)propanoic acid (Ketoprofen). 3-Vinylbenzophenone was obtained from 3-bromobenzophenone by a Pd-catalyzed Heck coupling reaction. Pd-catalyzed carbonylation of this olefin gave the isopropyl $\alpha$-(3-benzoylphenyl) propionate in high yield (95\%) and with high regioselectivity (>99.5\%). Ketoprofen was obtained in $90 \%$ yield by hydrolysis of the isopropyl ester. It was also obtained in two steps from $3-$ vinylbenzophenone by a Ni-catalyzed hydrovinylation selectively affording 3-(3'-benzoylphenyl)-1-butene, followed by an oxidation. 3-Ethynylbenzophenone was obtained from 3bromobenzophenone by Pd-catalyzed coupling reaction. By means of a Pd-catalyzed carbonylation, this alkyne was converted regioselectively (97\%) into methyl $\alpha$-(3-benzoylphenyl) acrylate (93\% yield). Hydrolysis of the ester afforded the $\alpha$-(3-benzoylphenyl)acrylic acid. Asymmetric hydrogenation of this acid to give (S)-ketoprofen in $95 \%$ optical yield was achieved using a chiral Ru-(S)-BINAP catalyst.

Keywords: ketoprofen, carbonylation, hydrovinylation, hydrogenation

\section{Introduction}

Homogeneous catalysis has been responsible for many major recent developments in synthetic organic chemistry 1,2 . The combined use of organometallic and coordination chemistry has led to a number of new powerful synthetic methods involving the selective formation and/or cleavage of C-C and C-heteroatom bonds. An appropriate choice of central metal and a careful molecular design of coordinated ligands, especially with regard to electronic and steric properties, have resulted in the development of active and selective (chemo, regio- and enantioselective) catalytic systems. Over the past years we have focused our attention on the synthesis of tran-

*e-mail: almonte@if.ufrgs.br sition metal complexes ${ }^{3}$, and their application in the selective transformation of organic unsatured substrates ${ }^{4-10}$.

$\alpha$-Arylpropionic acids are an important class of nonsteroidal anti-inflammatory agents with a multibillion-dollar market11. Among the numerous methodologies 12,13 for the synthesis of this class of drug, metal-catalyzed reactions appear to be of general utility and are very promising in racemic and asymmetric synthesis. In this work we show the application of homogeneous metal-based catalytic systems for the synthesis of Ketoprofen (Scheme 1).

Ketoprofen was developed by Rhône-Poulenc 14 and is commercialized in its racemic form in Brazil by Rhodia as Profenid. The synthesis of ketoprofen generally involves a multi-step reaction procedure 12 . Although many asymmetric syntheses for $\alpha$-arylpropionic acids have been devel- 


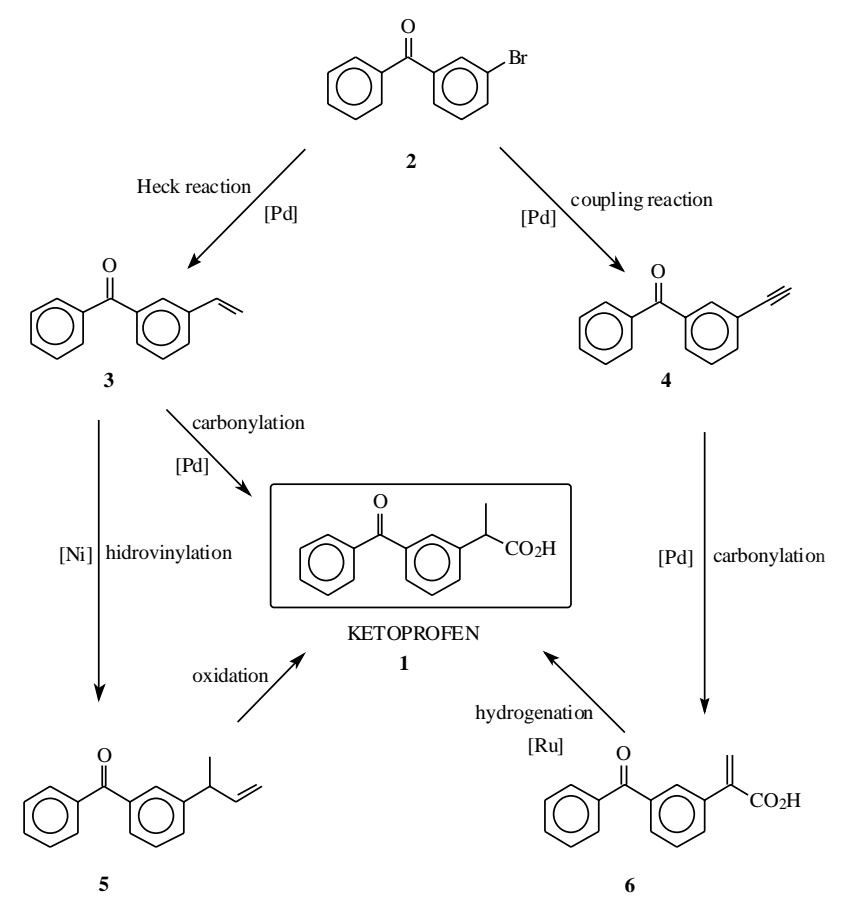

Scheme 1

oped, most of them are not amenable to Ketoprofen. In terms of enantioselective catalytic reactions, asymmetric hydrogenation 15 and epoxidation 16 reactions have been used as key steps. The hydrogenation of $\alpha$-(3-benzoylphenyl) acrylic acid using a chiral rhodium catalyst gave Ketoprofen in moderate enantiomeric excess (up to $69 \%)^{15}$. Another catalytic approach made use of a combination of Sharpless epoxidation followed by a stereoselective hydrogenolysis of a benzylic carbon-oxygen bond to establish the stereochemistry 16 . Using this approach, (S)-Ketoprofen was obtained in $98 \%$ ee in 11 steps starting from 3-bromoacetophenone. The other asymmetric syntheses described are not catalytic reactions and the stereoselectivity is achieved using a stoichiometric chiral auxiliary. For instance, $\alpha$-(3-benzoylphenyl)acetic acid was transformed into a chiral imide using oxazolidines as chiral auxiliaries 17 . Thereafter, the chiral imide was alkylated with methyliodide. Racemizing amide cleavage conditions did not afford (S)-Ketoprofen of sufficient enantiomeric purity and a later separation by recrystallisation of diastereoisomers resulting from reaction with (R)methylbenzylamine was necessary in order to obtain (S)Ketoprofen in $96 \%$ ee. Another approach started from racemic Ketoprofen which was transformed into a ketene 18,19. Diastereoselectivities for the addition of a chiral hydroxyl compound were, after saponication, Ketoprofen up to $71 \%$ for the chiral lactate 18 and up to $99 \%$ for (R)-pantolactone ${ }^{19}$. Finally, a photochemical rearrangement of $\alpha$-chloropropiophenones was used to ob- tain $\alpha$-arylpropionic acids in low optical yield in the case of Ketoprofen $(32 \%)^{20}$.

\section{Results and Discussion}

As depicted in Scheme 1, the starting material for different pathways in the synthesis of Ketroprofen (1) is 3bromobenzophenone (2). This aryl bromide was prepared in two steps from benzoic acid (Eq. 1)20. First, bromination of benzoic acid gave 3-bromobenzoic acid in 55\% yield. Second, the acid was converted into the acid chloride with $\mathrm{SOCl}_{2}$ which by a Friedel-Crafts reaction with $\mathrm{AlCl}_{3}$ and benzene afforded 2 in $90 \%$ yield.

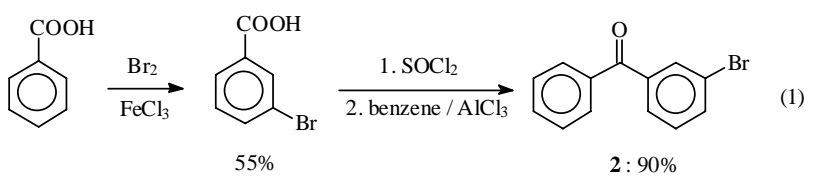

Heck reaction: synthesis of 3-vinylbenzophenone (3) and 3ethynylbenzophenone (4)

3-Vinylbenzophenone (Eq. 2) and 3-ethynylbenzophenone (Scheme 2) can be obtained from 2 by a palladiumcatalyzed coupling 21. Coupling of 3-bromobenzophenone with ethylene was carried out under Heck conditions 22 . Thus, using a catalytic system composed of $\mathrm{Pd}(\mathrm{OAc})_{2}$ and tri-o-tolylphosphine, $\mathbf{2}$ dissolved in acetonitrile, was coupled with ethylene (20 atm) at $125^{\circ} \mathrm{C}$ giving 3-vinylbenzophenone (3) in good yield (80\%).

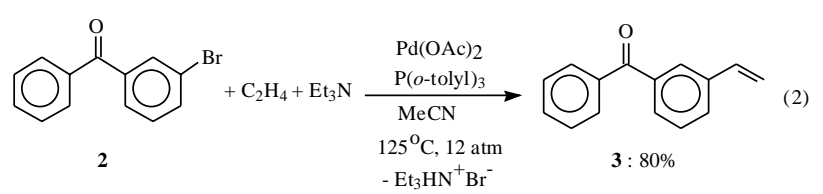

3-Bromobenzophenone was coupled with 2-methyl3-butyn-2-ol, an oily acetylene equivalent, under the Hagiahara's conditions ${ }^{23}$ to give 1-(3'benzoylphenyl)-3methyl-1-butyn-3-ol (7). Thus, using a catalytic system composed of $\mathrm{PdCl}_{2}\left(\mathrm{PPh}_{3}\right)_{2}$ and copper(I) iodide, 2 dissolved in diethylamine was coupled with $\mathbf{3}$ under reflux for $17 \mathrm{~h}$ to afford 7 in good yield (79\%). This compound upon treatment with alkali ${ }^{24}$ was converted into 3-ethynylbenzophenone (4) in $86 \%$ yield.

\section{Palladium-catalyzed carbonylation of3-vinylbenzophe-none(3)}

The transition metal-catalyzed carbonylation of organic substrates represents a very important process in organic synthesis. Indeed, carbon monoxide can be 


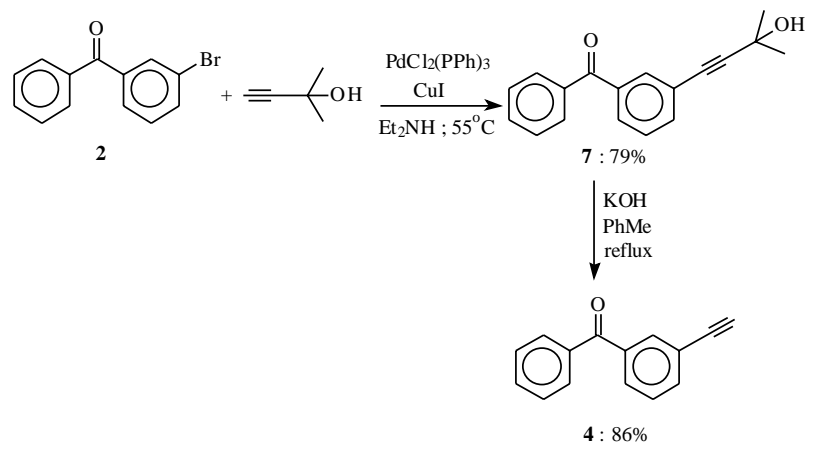

Scheme 2

directly introduced into unsaturated substrates to produce organic molecules such as aldehydes, ketones, esters, amides, and other carbonyl-containing functionalities ${ }^{25}$. Although many transition metal complexes are effective catalysts for carbonylation, palladium complexes are the most widely employed. In this respect, palladium-catalyzed carbonylation of styrene derivatives in the presence of alcohols (hydroesterification) affords $\alpha$-arylpropionic esters that are converted into $\alpha$-arylpropionic acids by hydrolysis. Recently, we demonstrated that palladium-based catalysts associated with a phosphine ligand and immobilized in 1-n-butyl-3-methylimidazoliumtetrafluoroborate are highly efficient for the biphasic regioselective hydroesterification of styrene derivatives under mild conditions ${ }^{4}$. The choice of the phosphine ligand is crucial on the regioselectivity and activity control and the best results were found using (+)-neomenthyldiphenylphosphine [(+)-NMDPP]. These conditions were applied to the carbonylation of 3-vinylbenzophenone in homogeneous media (Eq. 3).

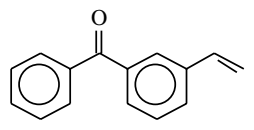

3

$+\mathrm{CO}+i \mathrm{PrOH}$

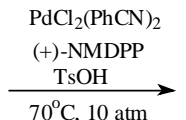

$70^{\circ} \mathrm{C}, 10 \mathrm{~atm}$

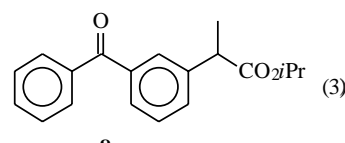

8

Yield: $95 \%$

Regioselectivity $>99.5 \%$
The carbonylation of $\mathbf{3}$ dissolved in a mixture isopropanol $(4 \mathrm{~mL}) /$ cyclohexane $(6 \mathrm{~mL})$ proceeds under $10 \mathrm{~atm}$ of $\mathrm{CO}$ at $70^{\circ} \mathrm{C}$ for $20 \mathrm{~h}$ using a catalytic system composed of $\mathrm{PdCl}_{2}(\mathrm{PhCN})_{2},(+)-\mathrm{NMDPP}$, and $p$-toluenesulfonic acid. Isopropyl $\alpha$-(3 benzoylphenyl) propionate (8) was obtained in high yield $(95 \%)$ and high regioselectivity $(\alpha: \beta$ $>99.5: 0.5$ ). Hydrolysis of the isopropyl ester with aqueous $\mathrm{KOH}$ followed by acidification with $\mathrm{HCl}$ gave Ketoprofen in $90 \%$ yield.

\section{Nickel-catalyzedhydrovinylation of 3-vinylbenzophenone(3)}

The catalytic hydrovinylation of styrene derivatives can be used to produce 3-aryl-1-butenes 26 . These olefins are converted into $\alpha$-arylpropionic acids by an oxidation reaction 27 . Moreover, they have also been used as monomers for the homopolymerization or copolymerization of olefins. We have shown that a catalytic system composed of $\left[\mathrm{Ni}(\mathrm{MeCN})_{6}\right]\left[\mathrm{BF}_{4}\right]_{2}$, triphenylphosphine and diethylaluminum chloride is active and regioselective for the hydrovinylation of styrene and alkylstyrenes ${ }^{7}$. However, low activities or inactivity were observed for styrene derivatives containing a Lewis basic group. Further studies have shown that these styrene derivatives can also be hydrovinylated by changing the relative ratios of the three catalyst components 28 . After intensive investigation of the hydrovinylation of 3-vinylbenzophenone we have pinpointed the reaction conditions and procedure which afford 3-(3'-benzoylphenyl)-1-butene (5) with both a high regioselectivity and yield (Eq. 4).

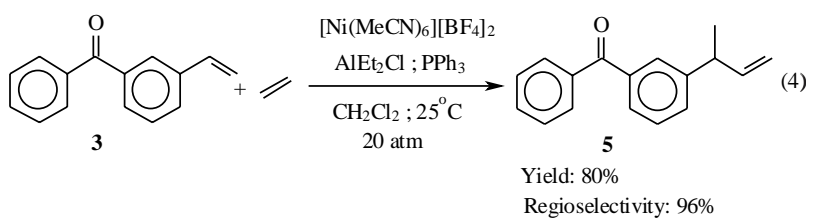

The hydrovinylation reaction was carried out using an $\mathrm{Al} / \mathrm{Ni}$ ratio $=25$ and $\mathrm{PPh}_{3} / \mathrm{Ni}$ ratio $=4$ to afford the hydrovinylated product in $80 \%$ isolated yield and $96 \%$ regioselectivity. It is interesting to note that in this case the addition order is crucial. In fact 3-vinylbenzophenone must be introduced only after the in situ formation of the catalyst (see experimental section). If it is introduced first, as described for the hydrovinylation of styrene ${ }^{7}$, the carbonyl group in $\mathbf{3}$ can interact with the organoaluminum Lewis acid preventing the formation of the nickel-hydride catalytic species. The observed chemoselectivity is presumably the result of the $\mathrm{Ni}-\mathrm{H}$ bond reacting faster with the activated $\mathrm{C}=\mathrm{C}$ bond of 3 than with that of ethylene and/or the higher stability of the $\eta^{3}$-benzylic-nickel compared with an ethylnickel intermediate. Steric effects of the triphenylphosphine ligand prevent a second styrene molecule from approaching the resulting $\mathrm{Ni}-\mathrm{C}$ bond, but not the smaller ethylene molecule, and as a result $\mathbf{3}$ is almost exclusively hydrovinylated as 3-(3'-benzoylphenyl)-1butene (5) and neither oligomerized or polymerized. Ketoprofen was obtained in $65 \%$ yield by oxidation of 5 with $\mathrm{KMnO}_{4} / \mathrm{NaIO}_{4}$. 


\section{Palladium-catalyzed carbonylation of 3-ethynylbenzo-phenone(4)}

Recently we described a simple method for the synthesis of chiral $\alpha$-arylacrylic esters by the carbonylation of arylacetylenes in the presence of chiral alcohols catalyzed by palladium complexes under mild conditions with high yields 5 . Two regioisomers can be obtained ( $\alpha$ and $\beta$ arylacrylic esters) and the regioselectivity depends on the phosphine ligand used. The selective carbonylation of $\mathbf{4}$ was performed using a catalytic system composed of $\mathrm{Pd}(\mathrm{dba})_{2}, \mathrm{PPh}_{3}$ and $p$-toluenesulfonic acid (Eq. 5). In the presence of methanol and operating under mild conditions $\left(10 \mathrm{~atm}, 100^{\circ} \mathrm{C}, 2 \mathrm{~h}\right.$ ), this catalytic system affords the methyl $\alpha$-(3-benzoylphenyl)acrylate (9) in a very good yield $(93 \%)$ and with high regioselectivity $(\alpha: \beta=97: 3)$. Hydrolysis of the methyl ester 9 with aqueous $\mathrm{KOH}$ followed by acidification with $\mathrm{HCl}$ gave the $\alpha$-(3-benzoylphenyl) acrylic acid (6) in almost quantitative yield.

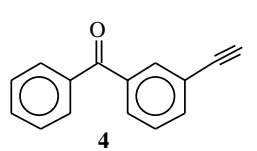

$+\mathrm{CO}+\mathrm{MeOH}$

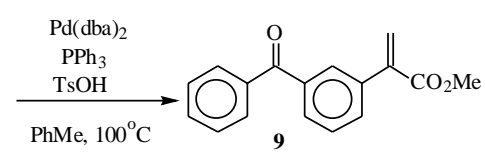

Yield: 93\% Regioselectivity: $97 \%$

\section{Ruthenium catalyzed asymmetric hydrogenation of} $\alpha$-(3-benzoylphenyl)acrylic acid (6)

The anti-inflammatory activity of $\alpha$-arylpropionic acids resides in the $(\mathrm{S})$-isomers but, with the exception of Naproxen where the (R)-isomer is a liver toxin, they are currently administered as racemates. However, in recent years the use of enantiomerically pure drugs has become almost mandatory not only to achieve enhanced specificity of drug action but to avert the possible toxicity and undesirable load on metabolism by the other enantiomer ${ }^{29}$.

(S)-Ketoprofen was obtained in moderate optical yield (up to 67\%) by asymmetric hydrogenation of $\alpha$-(3benzoylphenyl)acrylic acid using a rhodium homogeneous catalyst and (-)-DIOP as a chiral phosphine ligand ${ }^{15}$. A significant advance in chiral synthesis involves asymmetric hydrogenation reactions of $\alpha, \beta$-unsaturated acids catalyzed by Ru-BINAP complexes 30 . Noyori has demonstrated that the complex [(S)-BINAP]Ru(OAc) $)_{2}$ catalyzes the hydrogenation of $\alpha$-(6-methoxy-2-naphtyl)acrylic acid to (S)Naproxen in $92 \%$ chemical yield and with an enantiomeric purity of $97 \% 31$. Despite the relatively high pressure required (135-150 atm) for the reaction that may present a practical limitation, Monsanto patented an industrial process for the synthesis of (S)-Naproxen where the key-step is this asym- metric hydrogenation reaction 11 . Recently, we have shown that the asymmetric hydrogenation of $\alpha$-arylacrylic acids can be performed in presence of in situ or preformed Ru-BINAP catalyst precursors immobilized in an ionic liquid phase 6 . In comparison with the homogeneous reaction, similar or slightly increased optical yields were obtained. It is interesting to note that no significant effect of the hydrogen pressure was observed. At the end of the reaction the hydrogenated product can be separated by simple decantation and the ionic catalyst solution can be recycled without significant changes in activity and selectivity.

We performed the hydrogenation of $\alpha$-(3-benzoylphenyl) acrylic acid (6) in homogeneous media using the commercially available $\left[\mathrm{RuCl}_{2}-(\mathrm{S})-\mathrm{BINAP}\right]_{2} \cdot \mathrm{Et}_{3} \mathrm{~N}$ as catalyst (Eq. 6). The reaction was carried out in methanol at room temperature giving Ketoprofen in good yield. Although Ru-BINAP complexes have also been used in the hydrogenation of ketones ${ }^{30}$, only hydrogenation of the $\mathrm{C}=\mathrm{C}$ bond was observed under the conditions employed. On the other hand, the optical yields of the hydrogenation products depended on the reaction conditions. Under the conditions studied the optical yield in (S)-Ketoprofen improved from 43 to $70 \%$ upon increasing the hydrogen pressure from 30 to $70 \mathrm{~atm}$. In addition, an increase in the optical yield of (S)-Ketoprofen was observed due to the lowering of the temperature and the addition of an organic base. When the reaction was carried out at $-5 \circ \mathrm{C}$ and using triethylamine $\left(\mathrm{NEt}_{3} /\right.$ substrate $\left.=1\right)$ as a base promoter, $(\mathrm{S})$ Ketoprofen was obtained in $95 \%$ ee. Compared with the literature $12-20$, these results are a significant improvement in terms of the enantioselective synthesis of (S)-Ketoprofen. It is worthwhile to mention that the racemic catalytic carbonylation and hydrovinylation reactions described herein should be transposable into an asymmetric variant if a suitable chiral catalyst is found and this work is in progress.

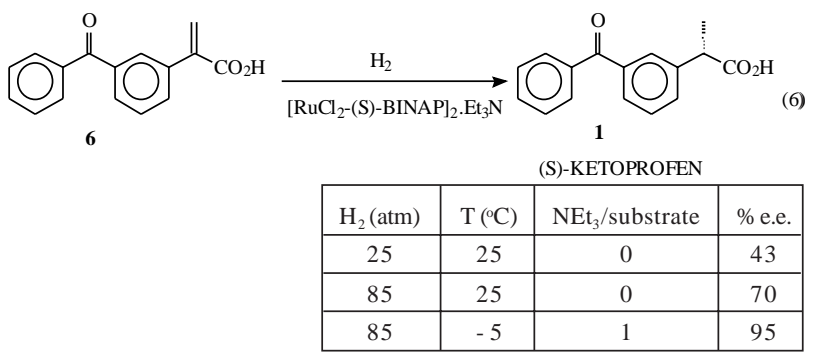

\section{Conclusions}

In this work, metal-catalyzed processes such as the Heck reaction, carbonylation, hydrovinylation and asymmetric hydrogenation were applied for the synthesis of an $\alpha$-arylpropionic acid (Ketoprofen) by different pathways. In each 
reaction, through the suitable choice of transition metal complex, ligand and experimental conditions, we have found an active catalytic system that operates under mild conditions with high selectivity.

\section{Experimental}

\section{General experimental procedures}

Catalytic reactions were performed under argon by standard manipulation of air-sensitive compounds. NMR spectra were recorded on a Varian VXR-200 or Varian XL 300. Infrared spectra were recorded on a Bomem B-102 spectrometer. Mass spectra were recorded on a GC/MS Shimadzu QP-5050 (EI, 70eV). Optical rotation values were recorded on a Perkin Elmer 341 polarimeter at $20^{\circ} \mathrm{C}$.

Solvents were dried under adequate drying agents and distilled under argon prior to use. $\mathrm{Pd}(\mathrm{dba})_{2}{ }^{32}$, $\mathrm{PdCl}_{2}(\mathrm{PhCN})_{2}{ }^{33}, \mathrm{PdCl}\left(\mathrm{PPh}_{3}\right)_{2}{ }^{34},\left[\mathrm{Ni}(\mathrm{MeCN})_{6}\right]\left[\mathrm{BF}_{4}\right]_{2}{ }^{3}, 3-$ bromobenzophenone 20 were synthesized as described in the literature. $\left[\mathrm{RuCl}_{2}-(\mathrm{S})-\mathrm{BINAP}\right]_{2} \cdot \mathrm{NEt}_{3}$ and $\mathrm{Pd}(\mathrm{OAc})_{2}$ were purchased from Strem and used without further purification. The other reagents were purchased from Aldrich and used without further purification.

\section{3-Vinylbenzophenone(3)}

A solution of $2(2.61 \mathrm{~g}, 10 \mathrm{mmol})$, palladium acetate (22.2 mg, $0.1 \mathrm{mmol}$ ) and tri-o-tolylphosphine (62 mg, 0.20 $\mathrm{mmol})$ in $\mathrm{CH}_{3} \mathrm{CN}(10 \mathrm{~mL})$ and $\mathrm{NEt}_{3}(5 \mathrm{~mL})$ was placed in a stainless steel autoclave under argon. Ethylene was introduced at the desired pressure (12 atm) with stirring to saturate the solution. The autoclave was stirred magnetically in an oil bath at $125^{\circ} \mathrm{C}$ for $4 \mathrm{~h}$. After cooling at room temperature and releasing the excess ethylene, the autoclave was opened. Water was added to the reaction mixture and the product was extracted with ether. The organic layer was dried over $\mathrm{MgSO}_{4}$, filtered off and the volatiles were removed under reduced pressure affording an orange oil. The crude product was purified by flash chromatography on silica gel (hexanes:ethyl acetate $=9: 1$ ) giving 3 as a colorless oil $(1.66 \mathrm{~g}, 80 \%) .{ }^{1} \mathrm{H} \mathrm{NMR}\left(\mathrm{CDCl}_{3}, 200 \mathrm{MHz}\right)$ $\delta 5.32(\mathrm{~d}, J 10.85 \mathrm{~Hz}, 1 \mathrm{H}), 5.80(\mathrm{~d}, J 17.60 \mathrm{~Hz}, 1 \mathrm{H}), 6.76$ (dd, $J 10.85 \mathrm{~Hz}, J 17.67 \mathrm{~Hz}, 1 \mathrm{H}), 7.24-7.82$ (m, 9H). IR $\left(v_{\text {max }} / \mathrm{cm}^{-1}\right) 3082,3058,1660,1625,1597,1447,1316$, 1280, 703 (neat). GC-MS (70 eV): $208\left(\mathrm{M}^{+}, 74 \%\right)$, 131(99\%), 105(100\%), 103 (35\%), 77(92\%), 51(41\%).

\section{3-Ethynylbenzophenone(4)}

2 (620 mg, $2.38 \mathrm{mmol}), \mathrm{PdCl}_{2}\left(\mathrm{PPh}_{3}\right)_{2}$ (16.7 mg, 0.024 $\mathrm{mmol})$, and copper(I) iodide ( $4.6 \mathrm{mg}, 0.024 \mathrm{mmol})$ were placed in a Schlenk tube under argon. To this mixture were added diethylamine (10 mL) and 2-methyl-3-butyn-2-ol (300.3 mg, $3.57 \mathrm{mmol}$ ), and the resulting mixture was heated to reflux for $23 \mathrm{~h}$. The insoluble material was filtered off and the excess diethylamine was evaporated under reduced pressure. The residue was dissolved in ether $(30 \mathrm{~mL})$ and washed successively with saturated aqueous $\mathrm{NaCl}, 10 \%$ aqueous citric acid $(3 \times 20 \mathrm{~mL})$, saturated aqueous $\mathrm{NaCl}(20 \mathrm{~mL}), 5 \%$ aqueous $\mathrm{NaHCO}_{3}(20 \mathrm{~mL})$, and finally with saturated aqueous $\mathrm{NaCl}(20 \mathrm{~mL})$, then dried over anhydrous $\mathrm{MgSO}_{4}$. Kugelrohr distillation at $2 \mathrm{~mm} \mathrm{Hg}$ and at $145^{\circ} \mathrm{C}$ gave 7 as colorless oil (353 mg, $79 \%)$ [ GC-MS (EI, $70 \mathrm{eV}): 264\left(\mathrm{M}^{+}, 15 \%\right), 249$ (66\%), 171 (35\%), 159 (19\%), 115 (15\%), 105 (100\%), 77 (64\%), 51 (27\%)].A mixture of 7 (353 mg, $1.34 \mathrm{mmol})$, powdered potassium hydroxide $(33.5 \mathrm{mg}, 0.6 \mathrm{mmol})$ and toluene $(10 \mathrm{ml})$ was heated to reflux for $4 \mathrm{~h}$ under an argon atmosphere. The excess toluene was evaporated under reduced pressure, and the residue was dissolved in ether $(30 \mathrm{~mL})$. The ethereal solution was washed successively with saturated aqueous $\mathrm{NaCl}(20 \mathrm{~mL}), 10 \%$ aqueous citric acid (3 x $20 \mathrm{~mL})$, saturated aqueous $\mathrm{NaCl}(20 \mathrm{~mL}), 5 \%$ aqueous $\mathrm{NaHCO}_{3}(20$ $\mathrm{mL})$ and finally with saturated aqueous $\mathrm{NaCl}(20 \mathrm{~mL})$. The solution was dried over anhydrous $\mathrm{MgSO}_{4}$, filtered and evaporated. Kugelrohr distillation at $2 \mathrm{~mm} \mathrm{Hg}$ and $125^{\circ} \mathrm{C}$ gave 4 as colorless oil (218 mg, $80 \%) .{ }^{1} \mathrm{H}$ NMR (200 MHz, $\left.\mathrm{CDCl}_{3}\right) \delta$ 3.12 (s, 1H), 7.44-7.84 (m, 9H). IR ( $\left.v_{\max } / \mathrm{cm}^{-1}\right) 3290,2923$, 2111, 1662, 1597, 1448, 1318, 1283, 720 (neat). GC-MS (EI, $70 \mathrm{eV}): 206\left(\mathrm{M}^{+}, 51 \%\right), 129$ (44\%), 105 (100\%), 101 (35\%), $77(57 \%), 75(19 \%), 51(44 \%), 50(14 \%)$.

\section{Carbonylation of 3-vinylbenzophenone (3)}

In a 100 ml-stainless steel autoclave under argon were placed $\mathrm{PdCl}_{2}(\mathrm{PhCN})_{2}(2.1 \mathrm{mg}, 0.0055 \mathrm{mmol}),(+)-\mathrm{NMDPP}$ (3.8 mg, $0.012 \mathrm{mmol}$ ), p-toluenesulfonic acid (4.6 mg, 0.027 $\mathrm{mmol}), 3$ (100 $\mathrm{mg}, 0.48 \mathrm{mmol})$, isopropanol (4 mL) and cyclohexane $(6 \mathrm{~mL})$. The reactor was pressurized with 10 atm of $\mathrm{CO}$ and the reaction mixture was stirred at $70^{\circ} \mathrm{C}$ for $20 \mathrm{~h}$. After cooling and releasing the excess carbon monoxide, the reaction mixture was analyzed by GC using naphthalene as an internal standard. Methyl $\alpha$-(3-benzoylphenyl) propionate (8) [GC-MS (EI, $70 \mathrm{eV}): 296\left(\mathrm{M}^{+}, 2 \%\right), 210$ (40\%), 209 (53\%), 105 (100\%), 103 (12\%), 78 (11\%), 77 (71\%), $51(18 \%)$ ] was obtained in $95 \%$ GC yield and $>99.5 \%$ regioselectivity. After concentration, water $(10 \mathrm{~mL})$ and $\mathrm{KOH}$ (150 mg) were added to the ester $\mathbf{8}$ and the mixture was stirred at room temperature for $24 \mathrm{~h}$. The aqueous solution was washed with ether $(3 \times 10 \mathrm{~mL})$ and acidified with concentrated $\mathrm{HCl}$ to $\mathrm{pH} 1$. Ketoprofen was extracted with ether $(3 \times 30 \mathrm{~mL})$, washed with saturated aqueous $\mathrm{NaHCO}_{3}(10$ $\mathrm{mL})$, water ( $2 \times 10 \mathrm{~mL})$ and dried with anhydrous $\mathrm{MgSO}_{4}$. 
Evaporation under vacuum gave Ketoprofen15 (104 mg, 90\%). ${ }^{1} \mathrm{H} \mathrm{NMR}\left(200 \mathrm{MHz}, \mathrm{CDCl}_{3}\right) \delta 1.48(\mathrm{~d}, J 7.1 \mathrm{~Hz}, 3 \mathrm{H})$, $3,78$ (q, J $7.1 \mathrm{~Hz}, 1 \mathrm{H}), 7.35-8.39$ (m, 9H), 9.4 (b, 1H). IR $\left(v_{\max } / \mathrm{cm}^{-1}\right) 3449,3062,2974,1717,1659,1597,1448$, $1318,1283,720,703$ (neat).

\section{Hydrovinylation of 3-vinylbenzophenone(3)}

A solution of $\left[\mathrm{Ni}(\mathrm{MeCN})_{6}\right]\left[\mathrm{BF}_{4}\right]_{2}(6.8 \mathrm{mg}, 0.0132 \mathrm{mmol})$ and $\mathrm{PPh}_{3}$ (14.8 mg, $\left.0.0564 \mathrm{mmol}\right)$ in dry $\mathrm{CH}_{2} \mathrm{Cl}_{2}(15 \mathrm{~mL})$ was placed in a $100 \mathrm{~mL}$ stainless steel autoclave under argon. The autoclave was purged with ethylene and $\mathrm{AlEt}_{2} \mathrm{Cl}$ (0.2 mL, $1.8 \mathrm{~mol} \mathrm{~L}^{-1}$ solution in toluene) and styrene (100 mg, $0.96 \mathrm{mmol}$ ) were added to the system. The autoclave was closed and the mixture was stirred at room temperature for 10 min under an ethylene atmosphere. After this time, a solution of $\mathbf{3}(269 \mathrm{mg}, 1.29 \mathrm{mmol})$ in dry $\mathrm{CH}_{2} \mathrm{Cl}_{2}(5 \mathrm{~mL})$ was added and the resulting mixture was stirred at room temperature for 1 $\mathrm{h}$ under $10 \mathrm{~atm}$ of ethylene. After releasing the excess of ethylene, the autoclave was opened and the solvent was evaporated. Kugelrohr distillation at $2 \mathrm{~mm} \mathrm{Hg}$ and $135^{\circ} \mathrm{C}$ gave 5 as colorless oil (239 mg, 80\%). ${ }^{1} \mathrm{H} \mathrm{NMR}\left(300 \mathrm{MHz}, \mathrm{CDCl}_{3}\right) \delta 1.32(\mathrm{~d}$, $J 7.08 \mathrm{~Hz}, 3 \mathrm{H}), 3.48$ (q, $J 6.81 \mathrm{~Hz}, 1 \mathrm{H}), 4.96-5.04$ (m, 2H); $5.86-6.03(\mathrm{~m}, 1 \mathrm{H}), 6.99-7.83(\mathrm{~m}, 9 \mathrm{H}) .{ }^{13} \mathrm{C} \mathrm{NMR}(300 \mathrm{MHz}$, $\left.\mathrm{CDCl}_{3}\right) \delta 20.7,43.0,113.8,128.1,128.2,128.4,128.7,130.0$, 131.4, 132.3, 137.7, 142.6, 145.9, 196.8. GC-MS (EI, 70 eV) $236\left(\mathrm{M}^{+}, 22 \%\right), 159$ (27\%), $131(80 \%), 105(100 \%), 91(15 \%)$, 77 (66\%), 51(22\%). IR ( $\left.v_{\max } / \mathrm{cm}^{-1}\right)$ 3082, 3076, 2965, 1659, 1598, 1577, 1447, 1440, 1282, 915, 715, 701 (neat).

\section{Oxidation of 3-(3'-benzoylphenyl)-1-butene(5)}

To a solution of 5 (90 mg, $0.38 \mathrm{mmol})$ in $10 \mathrm{~mL}$ of $\mathrm{BuOH}$ and $20 \mathrm{~mL}$ of water, $\mathrm{KMnO}_{4}(185 \mathrm{mg}, 1.17 \mathrm{mmol}), \mathrm{NaIO}_{4}$ (1.46 g, $6.86 \mathrm{mmol})$ and $\mathrm{K}_{2} \mathrm{CO}_{3}(366 \mathrm{mg}, 2.64 \mathrm{mmol})$ were added. The $\mathrm{pH}$ of the solution was adjusted to 8 with $3 \mathrm{~mol} \mathrm{L-}$ $1 \mathrm{aq} \mathrm{NaOH}$ and then the reaction mixture was stirred at room temperature for $3 \mathrm{~h}$. After this time the $\mathrm{pH}$ of the mixture was adjusted to 1 with concentrated $\mathrm{HCl}$ and $\mathrm{NaHSO}_{3}$ was added to reduce the $\mathrm{MnO}_{2}$. The mixture was washed with ether and the ethereal layer was extracted with $3 \mathrm{~mol} \mathrm{~L}^{-1}$ aqueous $\mathrm{NaOH}$. The aqueous layer was acidified with concentrated $\mathrm{HCl}$ and then extracted with ether. The organic layer was dried over $\mathrm{MgSO}_{4}$, filtered and the volatiles were removed under reduced pressure, yielding $\alpha$-(3-benzoylphenyl)propionic acid (Ketoprofen) as a colorless oil (63.2 mg, 65\%).

\section{Carbonylation of 3-ethynylbenzophenone (4)}

In a $100 \mathrm{~mL}$-stainless steel autoclave were placed 4 (218 $\mathrm{mg}, 0.9 \mathrm{mmol}$ ), bis-(dibenzylideneacetone)palladium (18.6 mg, 0,036mmol), $\mathrm{PPh}_{3}$ (37.8 mg, $0.14 \mathrm{mmol}$ ), $p$-toluenesulfonic acid (6.2 mg, $0.036 \mathrm{mmol}), \mathrm{MeOH}(22 \mu \mathrm{L}, 0.9 \mathrm{mmol})$ and toluene $(15 \mathrm{~mL})$. The mixture was stirred at $100^{\circ} \mathrm{C}$ for $2 \mathrm{~h}$ under $10 \mathrm{~atm}$ of carbon monoxide. After cooling and releasing the excess carbon monoxide, the reaction mixture was filtered over Celite and the solvent was evaporated under reduced pressure. Methyl $\alpha$-(3-benzoylphenyl)acrylate (9) was obtained in $93 \%$ GC yield and $97 \%$ regioselectivity [GC-MS (EI, 70 eV) $266\left(\mathrm{M}^{+}, 28 \%\right), 206(15 \%), 189(57 \%), 105(100 \%), 102(13 \%)$, 101 (13\%), 77 (79\%). After concentration, a $2 \mathrm{~mol} \mathrm{~L}^{-1} \mathrm{KOH}$ aqueous solution $(0.6 \mathrm{~mL})$ and acetone $(5 \mathrm{~mL})$ were added to the ester 9 and the mixture was stirred at room temperature for $16 \mathrm{~h}$. The aqueous solution was washed with ether $(20 \mathrm{~mL})$ and acidified with concentrated $\mathrm{HCl}$ to $\mathrm{pH} 1$. The organic acid was extracted with ether $(3 \times 30 \mathrm{~mL})$, washed with saturated aqueous $\mathrm{NaCl}(3 \times 30 \mathrm{~mL})$ and dried with anhydrous $\mathrm{Na}_{2} \mathrm{SO}_{4}$. Evaporation under vacuum gave $\alpha$-(3-benzoylphenyl) acrylic acid 35 (159 mg, 82\%). ${ }^{1} \mathrm{H} \mathrm{NMR}\left(200 \mathrm{MHz}, \mathrm{CDCl}_{3}\right.$,): $\delta 6.10$ (s, 1H), 6.61 (s, 1H), 7.29-8.00 (m, 9H), 9.40 (br, 1H).

\section{Hydrogenation of $\alpha-(3-$ benzoylphenyl)acrylic acid(6)}

In a $100 \mathrm{~mL}$-stainless steel autoclave under argon were placed 6 (59 mg, $0.23 \mathrm{mmol}),\left[\mathrm{RuCl}_{2}-(\mathrm{S})-\mathrm{BINAP}\right]_{2} . \mathrm{Et}_{3} \mathrm{~N}$ $(5.4 \mathrm{mg}, 0.0032 \mathrm{mmol})$ and methanol $(15 \mathrm{~mL})$. The reactor was pressurized with hydrogen ( $25 \mathrm{~atm}$ ) and stirred at room temperature for $22 \mathrm{~h}$. After releasing the excess hydrogen, the reaction mixture was filtered over Celite and the solvent was evaporated under reduced pressure. The residue was then acidified with $10 \% \mathrm{HCl}$ and extracted with ether ( $3 \times 20 \mathrm{~mL})$. The ethereal extract was washed with brine $(20 \mathrm{~mL})$ and dried over anhydrous $\mathrm{MgSO}_{4}$. The solvent was evaporated under reduced pressure giving $53 \mathrm{mg}$ of a mixture of $1(91 \%)$ and $6(9 \%)$. The optical rotation observed $\left\{[\alpha]_{D}=+140\left(\mathrm{c}=1.68\right.\right.$ in $\left.\left.\mathrm{CH}_{2} \mathrm{Cl}_{2}\right)\right\}$ showed an excess of the (S)-Ketoprofen enantiomer. The mixture of hydrogenated and unhydrogenated acids was transformed into their methyl esters \{methyl $\alpha$-(3benzoylphenyl)propionate: GC-MS (EI, $70 \mathrm{eV}) 268$ (M+, 27\%), 210 (12\%), 209 (72\%), 191 (19\%), 105 (100\%), 103 (20\%), 78 (14\%), 77 (95\%)\}. An enantiomeric excess of $43 \%$ was determined on a Varian-CX-3400 GC equipped with a chiral column CP-Chirasil-Dex CB ( $25 \mathrm{~m}$ x 0,25 $\mathrm{mm} \times 0,25 \mathrm{mmm}) ; \mathrm{P}_{\mathrm{H} 2}=20 \mathrm{psi} ;$ oven temperature $=150$ (isotherm); methyl ester of (S)-ketoprofen $=49.4 \mathrm{~min}$ and methyl ester of $(\mathrm{R})$-ketoprofen $=50.8 \mathrm{~min}$.

\section{Acknowledgements}

The authors acknowledge PADCT-CNPq for financial support, CAPES (D.Z.), FAPERGS (C.R.) and CNPq-RHAE (V.F.) for fellowships. V. R. Lando is a graduate student from 
CPGQUI-UNESP-Araraquara and acknowledges CNPq for a fellowship. We are grateful to Dr. D. John Spencer (Thrombosis Research Institute - Emmanuel Kaye Building -Manresa Road - London SW3 6LR) for proofreading the manuscript.

\section{References}

1. Parshall, G. W.; Ittel, S. D. Homogeneous Catalysis: The Applications and Chemistry of Catalysis by Soluble Transition Metal Complexes; John Wiley \& Sons; New York, 1992.

2. Noyori, R. Asymmetric Catalysis in Organic Synthesis; John Wiley \& Sons; New York, 1992.

3. Souza, R. F.; Monteiro, A. L.; Seferin, M.; Souza, M. O.; Stedile, F. C.; Wyrvalski, C. N.; Baumvol, I. J. R. J. Coord. Chem. 1996, 40, 311.

4. Zim, D.; Souza, R. F.; Dupont, J.; Monteiro, A. L. Tetrahedron Lett. 1998, 39, 7071.

5. Monteiro, A. L.; Lando, V. R.; Gasparini, V. Synth. Commun. 1997, 27, 3605.

6. Monteiro, A. L.; Zinn, F. K.; Souza, R. F.; Dupont, J. Tetrahedron: Asymmetry 1997, 8, 177.

7. Monteiro, A. L.; Seferin, M.; Dupont, J.; Souza, R. F. Tetrahedron Lett. 1996, 37, 1157.

8. Dani, P; Dupont, J.; Monteiro, A. L. J. Braz. Chem. Soc. 1996, 7, 15.

9. Souza, R. F.; Souza, M. O.; Monteiro, A. L.;Almeida, L.; Seferin, M. New. J. Chem. 1993, 17, 437.

10. Monteiro, A. L.; Souza, M. O.; Souza, R. F. Polymer Bull. 1996, 36, 331.

11. Chan, A. S. C. CHEMTECH 1993, 46-51.

12. a) Rieu, J. P.; Boucherle, A; Cousse, H.;Mouzin, G. Tetrahedron 1986, 42, 4095. For racemic Ketoprofen synthesis see also: b) Mitra, R. B.; Joshi, V. S. Synth. Commun. 1988, 18, 2259. b) Bennetau, B.; Krempp, M.; Dunoguès, J. Synth. Commun. 1994, 24, 77.

13. Sonawane, H. R.; Bellur, N. S.; Ahuja, J. R.; Kulkarni, D. G. Tetrahedron: Asymmetry 1992, 3, 163.

14. Brunet, J. P.; Cometti, A. (Societé des Usines Chimiques Rhône-Poulenc) Fr. 2,163,875 (1973). Chem. Abstr. 1974, 80, 14745.
15. Sunjic, V.; Habus, I.; Comisso, G.; Moimas, F. Gazz. Chim. Ital. 1989, 119, 229.

16. Hamon, D. P. G.; Mass-Westropp, R. A.; Newton, J. L. Tetrahedron 1995, 51, 12645.

17. Fadel, A. Synlet 1992, 48.

18. Schröder, G.; Arlt, D. Ger. Offen. DE 4,126,859 Chem. Abstr., 1993, 118, 254542.

19. Calmes, M.; Daunis, J.; Jacquier, R.; Natt, F. Tetrahedron 1994, 50, 6875.

20. Sonawane, H. R.; Bellur, N. S.; Kulkarni, D. G.; Ayyangar, N. R. Tetrahedron 1994, 50, 1243.

21. For a review see: a) Crisp, G. T. Chem. Soc. Rev. 1998 , 27, 427. b) Cabri, W.; Candiani, I. Acc. Chem. Res. 1995, 28, 2.

22. Plevyak, J. E.; Heck, R. F. J. Org. Chem. 1978, 43, 2454.

23. Takahashi, S.; Kuroyama, Y.; Sonogashira, K.; Hagihara, N. Synthesis, 1980, 627.

24. Ames, D. E.; Bull, D.; Takundwa, C. Synthesis, 1981, 364.

25. Colquhoun, H. M.; Thompson, D. J.; Twig, M. V. Carbo-nylation: Direct Synthesis of Carbonyl Compounds, Plenum Press, New York, 1991.

26. RajanBabu, T. V. in Comprehensive Asymmetric Catalysis; Jacobsen, E. N.; Pfaltz, A.; Yamamoto, H. Ed.; Springer; Berlin, 1999, Vol. 1, p 417.

27. Hayashi, T.; Iwamura, H.; Uozumi, Y.; Matsumoto, Y.; Ozawa, F. Synthesis 1994, 526.

28. Fassina, V.; Ramminger, C.; Seferin, M.; Monteiro, A.L. unpublished results.

29. Barreiro, E. J.; Ferreira, V. F.; Costa, P. R. R. Quím. Nova 1997, 20, 647.

30. Noyori, R. Asymmetric Catalysis in Organic Synthesis, John Wiley \& Sons, New York, 1994, pp 16.

31. Ohta, T.; Takaya, H.; Kitamura, M.; Nagai, K.; Noyori, R. J. Org. Chem. 1987, 52, 3174.

32. Rettig, M. F.; Maitlis, P. M. Inorg. Synth. 1977, 17, 134.

33. Doyle, J. R.; Slade, P. E.; Jonassen, H. B. Inorg. Synth. 1960, 6, 216.

34. Heck, R. F. Palladium Reagents in Organic Synthesis, Academic Press, New York, 1985, p. 18.

35. Comisso, G.; Mihalic, M.; Kajfez, F.; Sunjic, V. Gazz. Chim. Ital. 1980, 110, 123. 